\title{
PENGARUH KONTROL KELUARGA TERHADAP MANAJEMEN LABA
}

\author{
Ancilla Sheila Margono \\ Yulia Ivana Tanujaya \\ Athalia Ariati Hidayat \\ Retno Yuliati*
}

Departemen Akuntansi, Universitas Prasetiya Mulya, Jl. BSD Raya Barat 1 Serpong, Tangerang Selatan 15339

\begin{abstract}
The involvement of family in the company can lead to conflict between majority (family) and minority shareholders. This study aims to determine whether family control in companies listed on the Indonesia Stock Exchange (IDX) has a significant positive effect on earnings management. Earnings management in this research is measured using the Modified Jones Model. With a sample of 436 non-financial companies listed on the Stock Exchange in the period 2012-2016 and using the generalized least squares $(G L S)$ regression method, the study found that family control had a significant positive effect on earnings management. This indicates that family control in companies listed on the Stock Exchange tends to do earnings management.
\end{abstract}

Keywords: Family Control, Earnings Management, Modified Jones Model

\begin{abstract}
Abstrak
Keterlibatan keluarga dalam perusahaan dapat menimbulkan konflik antara pemegang saham mayoritas (keluarga) dan minoritas. Penelitian ini bertujuan untuk mengetahui apakah kontrol keluarga di perusahaan yang terdaftar pada Bursa Efek Indonesia (BEI) berpengaruh positif signifikan terhadap tindakan manajemen laba. Manajemen laba pada penelitian ini menggunakan model dari Modified Jones Model. Dengan sampel sebanyak 436 perusahaan non-finansial yang terdaftar pada BEI pada periode 2012-2016 menggunakan metode regresi generalized least squares (GLS), penelitian menemukan bahwa kontrol keluarga memiliki pengaruh positif signifikan terhadap manajemen laba. Hal ini menandakan bahwa adanya kontrol keluarga di dalam perusahaan terdaftar di BEI cenderung melakukan manajemen laba.
\end{abstract}

Kata Kunci : Kontrol Keluarga, Manajemen Laba, Modified Jones Model

\section{Pendahuluan}

Struktur kepemilikan keluarga dalam perusahaan memainkan peran penting di dalam ekonomi global (Prencipe, Bar-Yosef, dan Dekker, 2014). Setiap tahun, perusahaan dengan struktur kepemilikan keluarga dapat menghasilkan sekitar 70 hingga 90 persen GDP global (Family Firm Institute, 2008). Hal ini dikarenakan mayoritas bentuk kepemilikan perusahaan di dunia adalah perusahaan yang dikontrol oleh keluarga (La Porta, Lopez-DeSilanes dan Shleifer, 1999). Terlihat dari beberapa negara yaitu Uni Eropa dan Amerika Serikat, sekitar 85 persen bisnis dikelola oleh keluarga (Chris Razook, 2016). Demikian pula di Asia Tenggara termasuk di Indonesia, berdasarkan survei PriceWaterhouseCooper tahun 2014, lebih dari 95 persen perusahaan merupakan bisnis keluarga.

\footnotetext{
*Alamat kini: Universitas Prasetiya Mulya, Jl. BSD Raya Barat 1 Serpong, Tangerang Selatan 15339

Penulis untuk Korespondensi: Telp. (021) 30450500 ext. 2233, Email: retno.yuliati@pmbs.ac.id
} 
Chen dan Cheng (2008) mengungkapkan bahwa definisi perusahaan keluarga dapat dilihat dari bentuk pengelolaan organisasi yang anggota keluarga pendiri masih menempati posisi teratas di bidang manajemen. Menurut Anderson dan Reeb (2003), sebuah perusahaan keluarga ditandai dengan adanya kepemilikan saham keluarga dan (atau) keluarga menempati posisi manajemen. Di Indonesia, menurut Jakarta Consulting Group (2014) perusahaan keluarga pada awalnya dimiliki oleh satu orang saja yang akan mengembangkan perusahaan. Setelah perusahaan mulai berkembang, pendiri akan mengajak anak dan saudaranya bahkan menjadi dinasti keluarga karena mereka memiliki visi dan tujuan yang sama.

Dengan adanya keterlibatan keluarga di dalam suatu perusahaan, biasanya akan beberapa konflik salah satunya adalah pemegang saham mayoritas (keluarga) dan pemegang saham minoritas lainnya (Anderson dan Reeb, 2004). Konflik antara pemegang saham mayoritas dan minoritas sering timbul di negara-negara berkembang (Diyanty, Utama, Rossieta, dan Veronica, 2013).

Selain itu, pemilik keluarga juga memerlukan kebutuhan afektif yang dilihat dari aspek nonekonomi bisnis seperti identitas, kemampuan untuk menggunakan pengaruh dari keluarga, serta kebertahanan dari suatu dinasti keluarga yang sering disebut socio-emotional wealth (Gómez-Mejía, Haynes, Núñez-Nickel, Jacobson, dan Moyano-Fuentes, 2007). Dalam mencapai socio-emotional wealth, keluarga akan bersedia membuat keputusan yang tidak dapat dijelaskan secara finansial dan tindakan tidak profesional menjadi logis untuk memenuhi keinginan keluarga.

Salah satu hal yang dapat terjadi di perusahaan keluarga dikarenakan masalah keagenan dan teori socio-emotional wealth adalah manajemen laba. Saat ini, manajemen laba telah mencapai tingkat yang signifikan dan membahayakan integritas pelaporan keuangan (Healy dan Wahlen, 1999). Manajemen laba merupakan intervensi manajemen pada proses penyusunan laporan keuangan sehingga dapat menaikkan maupun menurunkan hasil pelaporan laba (Scott, 2015).

Namun, masih terdapat inkonsistensi dari beberapa penelitian yang telah dilakukan mengenai manajemen laba yang terjadi di perusahaan keluarga. Penelitian dari Jiraporn dan Dedalt (2009) mengungkapkan bahwa perusahaan keluarga lebih tidak melakukan manajemen laba dibandingkan perusahaan nonkeluarga dikarenakan ingin menjaga reputasi perusahaan dalam menjaga keberlangsungan perusahaan. Di sisi lain, penelitian Chi, Hung, Cheng, dan Tien Lieu (2015) menyatakan bahwa perusahaan keluarga melakukan manajemen laba yang dikarenakan adanya penyalahgunaan kekuasaan dari keluarga untuk kepentingan mereka. Penelitian dari Setia-Atmaja et al., (2011) juga menyatakan bahwa perusahaan keluarga mempunyai akrual diskresioner yang lebih tinggi.

Adanya inkonsistensi mengenai penelitian yang telah ada dan sebagian besar perusahaan di Indonesia merupakan perusahaan keluarga membuat penelitian ini menarik untuk diteliti. Oleh karena itu, riset ini dilakukan dengan tujuan untuk menganalisis pengaruh kontrol keluarga terhadap manajemen laba. Riset ini diharapkan dapat memberikan kontribusi bagi pengembangan ilmu bidang akuntansi karena menyediakan bukti empiris hubungan antara kepemilikan keluarga dan manajemen laba. Selain itu kontribusi praktis bagi investor untuk lebih memahami karakteristik perusahaan keluarga di Indonesia sebelum mengambil keputusan investasi.

\section{Telaah literatur dan pengembangan hipotesis}

\section{Teori Agensi}

Teori agensi menjelaskan hubungan asimetri antara principal dan agent (Jensen dan Meckling, 1976). Pada teori agensi, disebutkan bahwa principal dan agent memiliki tujuan yang berbeda sehingga hal tersebut dapat menimbulkan perbedaan kepentingan antar keduanya. Agent atau manajer suatu perusahaan cenderung akan mengejar tujuan pribadi sedangkan principal memiliki tujuan untuk kesejahteraan para pemegang saham serta menghasilkan laba yang baik dalam jangka panjang.

Terdapat beberapa tipe mengenai agency problem yaitu agency problem I dan agency problem II. Agency problem I terkait dengan pemisahan antara kepemilikan dan kontrol, serta adanya perbedaan kepentingan antara manajemen dan pemilik. Agency problem II yaitu terkait dengan kontrol keluarga terhadap suatu perusahaan yang timbul dari perbedaan kepentingan antara pemegang saham mayoritas dan minoritas (Anderson dan Reeb, 2004). Agency problem I biasanya muncul di perusahaan yang memiliki konsentrasi kepemilikan menyebar dan tidak hanya terkonsentrasi pada satu pemilik saja seperti di 
negara Amerika Serikat sedangkan agency problem II muncul karena adanya perbedaan kepentingan antara pemegang saham pengendali dan nonpengendali. Biasanya, agency problem II muncul di perusahaan yang terkonsentrasi di tangan pemegang saham tunggal. Adanya dominasi keluarga pada suatu perusahaan, maka muncul perbedaan kepentingan antara majority dan minority shareholder (agency problem II) (Salvato dan Moores, 2010).

\section{Socio-Emotional Wealth Theory}

Teori socio-emotional wealth mencakup tentang kebutuhan afektif dari suatu pemilik keluarga yang dilihat dari aspek nonekonomi bisnis seperti identitas, kemampuan untuk menggunakan pengaruh dari keluarga, serta keberlangsungan dari suatu dinasti keluarga (Gómez-Mejía et al., 2007).

Teori Socio-Emotional Wealth dikembangkan secara khusus dalam bidang penelitian bisnis keluarga oleh Prencipe et al., (2014) yang menekankan adanya gagasan bahwa keluarga dimotivasi dan berkomitmen untuk menjaga "nilai-nilai yang terkait dengan nonkeuangan". Dalam memperjelas Teori SocioEmotional Wealth, maka Prencipe et al., (2014) memberikan ilustrasi sebagai berikut;

“.... Fullfilment of the needs for belonging, affect and intimacy; identification of the family with the firms; desire to exercise authority and to retain influence and control within the firm; continuation of family values through the firm; preservation of family firm social capital and the family dinasty; discharge of familiar obligations; and the capacity to act altruistically towards family members using firm resources."

Ilustrasi tersebut menjelaskan bahwa "nilai-nilai yang terkait dengan nonkeuangan" digambarkan seperti rasa kepemilikan perusahaan, pengaruh keluarga, serta kontrol atas perusahaan. Keluarga cenderung ingin mempertahankan nilai-nilai keluarga yang telah ditanamkan. Selain itu, suatu keluarga dalam perusahaan akan mementingkan kepentingan keluarganya sendiri di atas kepentingan yang lain.

Kalm dan Gomez-Mejia (2016) juga mengatakan bahwa keluarga akan bersedia membuat keputusan yang tidak dapat dijelaskan secara finansial dan tidak profesional menjadi logis untuk memenuhi keinginan keluarga dalam mencapai socio-emotional wealth. Oleh karena itu, teori dari Socio-Emotional Wealth ini dapat memungkinkan adanya konflik kepentingan antara pemegang saham mayoritas (keluarga) dan minoritas yang sering disebut dengan agency problem II.

\section{Perusahaan Keluarga}

Struktur kepemilikan perusahaan terbagi menjadi dua yaitu struktur kepemilikan tersebar dan struktur kepemilikan terkonsentrasi. Mayoritas perusahaan yang berada pada wilayah United States serta United Kingdom memiliki struktur kepemilikan tersebar (Diyanty, Utama, Rossieta, dan Veronica, 2013). Dengan demikian, perusahaan tersebut cenderung lebih menghadapi Agency Problem Type I yaitu adanya konflik kepentingan antara principal dan agent (Jensen dan Meckling, 1976). Namun, berbeda dengan perusahaan di daerah Asia seperti Malaysia, Korea Selatan, Thailand, Filipina, serta Indonesia, beberapa negara tersebut memiliki struktur kepemilikan yang terkonsentrasi pada satu kepemilikan seperti kepemilikan keluarga pada suatu perusahaan (Claessens, Djankov, dan Lang, 2000). Penelitian oleh Diyanty et al., (2013) juga menyatakan bahwa sekitar 50 persen perusahaan terbuka di Indonesia adalah perusahaan dengan struktur kepemilikan terkonsentrasi serta dikendalikan oleh keluarga. Pada perusahaan yang memiliki struktur kepemilikan terkonsentrasi, seringkali menghadapi agency problem type II yaitu konflik antara pemegang saham mayoritas dan minoritas. Konflik terjadi karena pemilik perusahaan memiliki kontrol yang kuat atas perusahaan.

Menurut Villalonga, Belen dan Amit, Raphael (2006), sebuah perusahaan dapat dikategorikan sebagai perusahaan keluarga apabila struktur kepemilikan setidaknya 20 persen di tangan orang yang memiliki tingkat kekerabatan, hak suara atau kontrol yang signifikan. Chen dan Cheng (2008) mengungkapkan bahwa definisi perusahaan keluarga dapat dilihat dari bentuk pengelolaan organisasi yang anggota keluarga pendiri masih menempati posisi teratas di bidang manajemen. Menurut Anderson dan Reeb (2003), perusahaan keluarga dapat ditandai dengan adanya kepemilikan saham keluarga dalam perusahaan dan (atau) perusahaan dikendalikan serta dikelola oleh anggota keluarga.

\section{Manajemen Laba}

Manajemen laba merupakan intervensi manajemen pada proses penyusunan laporan keuangan sehingga dapat menaikkan maupun menurunkan hasil pelaporan laba (Scott, 2015). Healy dan Wahlen (1999) mengungkapkan 
bahwa manajemen laba merupakan tindakan yang disengaja dan bertujuan untuk mempengaruhi proses pelaporan keuangan perusahaan untuk mendapatkan keuntungan bagi kepentingan pribadi. Menurut Scott (2015), terdapat dua sudut pandang mengenai manajemen laba yaitu opportunistic earning management dan efficient earning management. Pada efficient earning management, akrual diskresioner memiliki hubungan positif dengan laba yang akan datang sedangkan pada opportunistic earning management, akrual diskresioner akan memiliki hubungan yang negatif dengan laba yang akan datang (Siregar dan Utama, 2008).

Dalam menghitung manajemen laba, terdapat beberapa model pengukuran yaitu $D e$ Angelo Model, Healy Model, Jones Model, Modified Jones Model dan Kothari Model. Dari beberapa model pengukuran manajemen laba, masing-masing memiliki kelemahan serta kelebihan yang dimiliki. Healy Model (1985) merupakan model yang relatif sederhana dengan menghitung total akrual sebagai proksi manajemen laba. DeAngelo (1986) mengukur akrual diskresioner dengan menghitung selisih total akural periode $\mathrm{t}$ dan $\mathrm{t}-1$. Jones Model (1991) menggunakan dasar model Healy (1985) yang dikembangkan lagi dengan memisahkan akrual diskresioner dari akrual nondiskresioner. Pengukuran yang paling banyak digunakan oleh beberapa peneliti yaitu Modified Jones Model. Model pengukuran ini merupakan modifikasi dari Jones Model (1991) dan dirancang untuk mengurangi adanya kesalahan dalam mengukur akrual diskresioner ketika menghitung pendapatan.

Pada Jones Model (1991), perhitungan pendapatan hanya menggunakan REV (Revenue) sedangkan pada Modified Jones Model ditambahkan Receivable dalam menghitung pendapatan. Asumsi dari Modified Jones Model yaitu perubahan dari penjualan kredit dapat menghasilkan manajemen laba. Untuk menghitung akrual diskresioner, total akrual dikurangkan dengan nondiskresioner akrual (Dechow, Sloan, dan Sweeney, 1995). Akrual diskresioner merupakan akrual yang timbul karena manipulasi manajer, sedangkan akrual nondiskresioner adalah akrual yang timbul karena kegiatan operasional perusahaan (Jones, 1991). Terdapat pengembangan dari Modified Jones Model yaitu Kothari, Leone, dan Wasley, (2005) dengan menambahkan kontrol kinerja dalam pengukuran manajemen laba. Kothari et al., (2005) memilih untuk menggunakan ROA dalam mengukur kinerja karena dianggap dapat meminimalisasi permasalahan yang terjadi pada model akrual yang ada, sehingga Kothari et al., (2005) menambahkan variabel ROA dalam model pengukuran Modified Jones. Namun, di sisi lain penelitian Suyono (2017) mengemukakan bahwa dengan adanya penambahan kontrol kinerja dalam pengukuran Kothari, jarang menghilangkan kekeliruan dan dapat menambah kekeliruan dalam perhitungan manajemen laba.

\section{Pengembangan Hipotesis}

Para akademisi mulai menaruh minat dan perhatian pada perusahaan keluarga sebagai penentu fenomena bisnis (Prencipe et al., 2014). Hal ini dikarenakan perusahaan keluarga memainkan peran penting pada ekonomi global. Mayoritas pasar global merupakan perusahaan yang dikontrol oleh keluarga (La Porta et al., 1999). Tidak terkecuali yaitu negara Indonesia, yang berdasarkan survei PriceWaterHouseCooper 2014, 95 persen perusahaan di negara Indonesia merupakan perusahaan keluarga.

Dalam perusahaan keluarga, sering ditemui adanya masalah keagenan yaitu agency problem type II karena adanya perbedaan kepentingan antara pemegang saham mayoritas dan minoritas (Ali, Chen, dan Radhakrishnan, 2007). Didukung juga oleh penelitian Fan dan Wong (2002) bahwa pemilik pengendali seperti dalam perusahaan keluarga sering dikaitkan dengan rendahnya earning informativeness. Selain masalah keagenan, adanya teori socioemotional wealth membuat keluarga akan bersedia membuat keputusan yang tidak dapat dijelaskan secara finansial dan tidak profesional menjadi logis untuk memenuhi keinginan keluarga.

Salah satu tindakan yang dapat terjadi terkait dengan masalah keagenan dan socioemotional wealth pada perusahaan keluarga adalah manajemen laba. Tujuan perusahaan keluarga yaitu dengan menyembunyikan tindakan yang dilakukan dalam upaya merugikan pemegang saham minoritas (Jaggi, Leung, dan Gul, 2009).

Pada penelitian sebelumnya, adanya kontradiksi yang menyatakan bahwa perusahaan keluarga cenderung melakukan manajemen laba dibandingkan perusahaan nonkeluarga. Jiraporn dan Dedalt (2009) menyatakan bahwa perusahaan keluarga tidak melakukan manajemen laba dibandingkan dengan perusahaan nonkeluarga. Penelitian di Indonesia 
juga mengatakan bahwa kepemilikan keluarga tidak berpengaruh signifikan dengan tindakan manajemen laba (Rezeki, Azlina, dan Kurnia, 2016). Namun di sisi lain, Chi et al., (2015) menyatakan bahwa perusahaan keluarga lebih banyak melakukan manajemen laba dibandingkan perusahaan nonkeluarga.

Setia-Atmaja et al., (2011) juga menyatakan bahwa perusahaan keluarga di Australia memiliki akrual diskresioner yang lebih tinggi. Hal ini dikarenakan pemilihan manajer dan direksi oleh keluarga dapat menimbulkan adanya nepotisme dan managerial entrenchment yang lebih tinggi (Anderson dan Reeb, 2004). Masalah keageanan pada perusahaan keluarga juga menyebabkan biaya agensi yang lebih tinggi dibandingkan dengan perusahaan nonkeluarga karena keengganan keluarga untuk memecat anggota keluarga yang tidak kompeten dalam perusahaan. Schulze et al., (2001) juga menyatakan bahwa pengelolaan masalah agensi dalam perusahaan keluarga akan lebih sulit karena adanya keinginan orang tua yang memiliki insentif untuk bermurah hati kepada anak-anak mereka seperti menghamburhamburkan uang orang tua.

Penelitian dari Almeida-Santos et al., (2013) mengatakan bahwa perusahaan keluarga di Brazil akan cenderung melakukan manajemen laba dengan memperburuk hasil di masa sekarang demi memperoleh hasil yang lebih baik pada masa yang akan datang. Perusahaan keluarga cenderung kurang sensitif dibandingkan dengan perusahaan nonkeluarga, terutama yang berhubungan dengan fluktuasi pasar pada jangka pendek, karena perusahaan keluarga memfokuskan diri pada hasil yang baik pada jangka panjang, daripada memaksimalkan kekayaan pemegang saham pada jangka pendek (Prencipe et al., 2008). Terdapat penelitian di Indonesia yaitu menurut Nayiroh (2012) dan Siregar dan Utama (2008) yang mengungkapkan bahwa struktur kepemilikan keluarga di perusahaan Indonesia dapat memengaruhi adanya tindakan manajemen laba. Hal ini dikarenakan adanya penyalahgunaan kekuasaan dari keluarga untuk kepentingan mereka. Hasil dari penelitian Siregar dan Utama (2008) menjelaskan lebih lanjut bahwa perusahaan keluarga lebih akan melakukan manajemen laba efisien.

Adanya keluarga sebagai pemegang saham mayoritas yang akan menimbulkan perbedaan kepentingan dengan pemegang saham minoritas dan keluarga juga dapat melakukan tindakan yang tidak profesional menjadi logis untuk mencapai rasa socio-emotional wealth, maka penelitian ini menganalisis hubungan positif antara perusahaan keluarga dengan manajemen laba di Indonesia dan dirumuskan hipotesis sebagai berikut:

\section{$H_{1}:$ Kontrol keluarga berpengaruh positif terhadap tindakan manajemen laba perusahaan}

\section{Faktor-faktor Lain yang Memengaruhi Manajemen Laba}

Terdapat beberapa faktor yang dapat memengaruhi tindakan manajemen laba. Faktor tersebut antara lain profitabilitas, leverage, growth, umur perusahaan, auditor eksternal perusahaan, industri dan tahun.

Penelitian dari Widyastuti (2009) mengatakan bahwa profitabilitas yang baik membuat perusahaan melakukan manajemen laba untuk menarik investor. Profitabilitas dapat dilihat dari berbagai faktor, salah satunya yaitu variabel ROA yang menunjukkan kemampuan perusahaan dengan memanfaatkan total aktiva untuk menghasilkan laba. Perusahaan yang memiliki profitabilitas yang tinggi akan mendorong perusahaan dalam melakukan manajemen laba dibandingkan dengan perusahaan yang memiliki profitabilitas lebih rendah karena manajemen mengetahui bagaimana kemampuan perusahaan dalam memperoleh laba pada masa depan.

Leverage juga merupakan salah satu faktor dalam perusahaan melakukan manajemen laba. Perusahaan dengan leverage yang tinggi menunjukkan bahwa utang yang dimiliki lebih besar dibandingkan dengan aset perusahaan (Bestivano, 2013). Dari sisi investor, mereka akan lebih memilih perusahaan dengan leverage yang lebih rendah karena resiko yang dihadapi semakin rendah. Dengan demikian, perusahaan dengan leverage yang tinggi memiliki dorongan untuk melakukan manajemen laba.

Selain leverage, umur perusahaan juga dapat memengaruhi perusahaan dalam melakukan tindakan manajemen laba (Bestivano, 2013). Perusahaan yang telah lama berdiri akan mendapat kepercayaan dari investor. Oleh karena itu, perusahaan yang baru berdiri biasanya lebih sedikit mendapatkan kepercayaan dari investor sehingga untuk mendapatkan kepercayaannya maka perusahaan melakukan manajemen laba.

Growth yaitu pertumbuhan penjualan dapat mempengaruhi adanya tindakan manajemen laba. Manajer melakukan 
manajemen laba dengan membuat pertumbuhan penjualan yang baik untuk menghindari adanya penurunan pendapatan (Handayani dan Rachadi, 2009).

Auditor eksternal yang mengaudit perusahaan akan mempengaruhi tindakan manajemen laba (Rusmin, 2010). Perusahaan yang diaudit oleh KAP Big 4, tingkat tindakan manajemen laba akan lebih rendah dibandingkan dengan KAP nonBig 4 karena KAP Big 4, ingin menjaga reputasi dari KAP sehingga KAP akan mencegah, mendeteksi, dan membatasi adanya praktik manajemen laba.

Faktor lain yang memengaruhi manajemen laba yaitu industri dan tahun.
Penelitian Almeida-Santos et al., (2013) mengungkapkan bahwa variabel industri berpengaruh terhadap praktik manajemen laba. Setiap industri dan tahun memiliki kondisi finansial yang berbeda sehingga dapat memengaruhi adanya tindakan manajemen laba di perusahaan.

\section{Kerangka Pemikiran}

Berdasarkan telaah literatur dan pengembangan hipotesis di atas, dapat digambarkan kerangka pemikiran sebagai berikut:

\section{Gambar 1 \\ Kerangka Pemikiran}

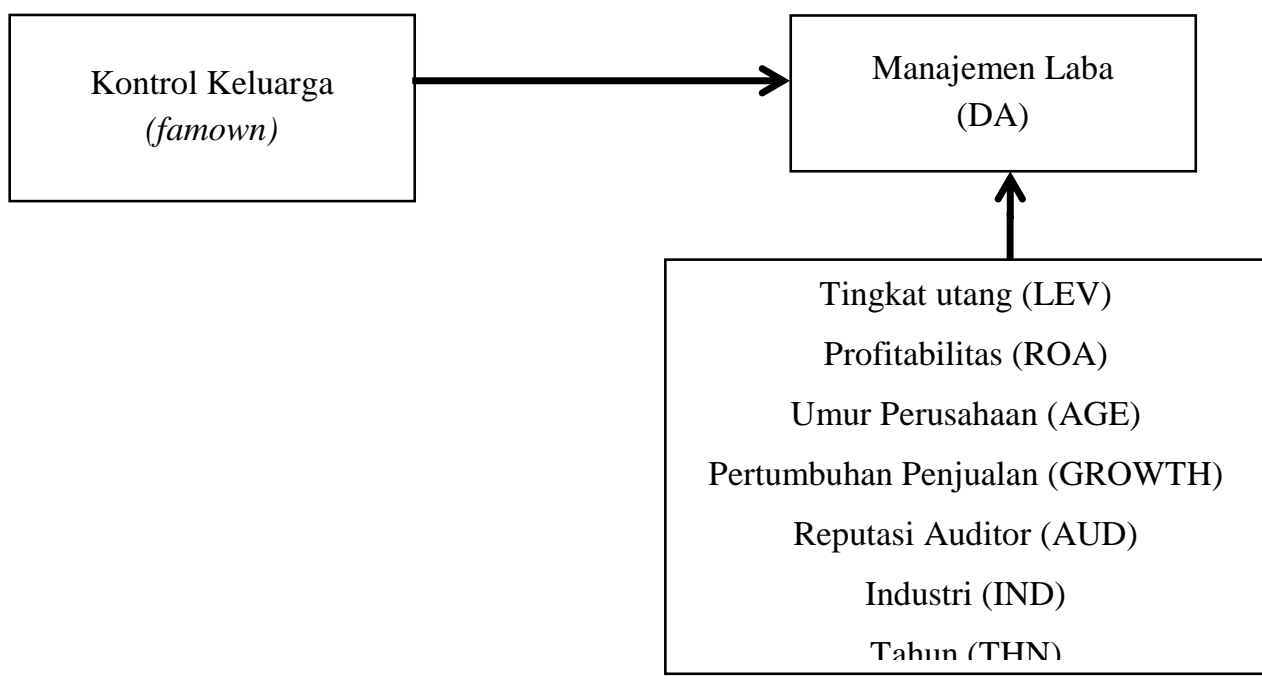

\section{Metode Penelitian}

\section{Data dan Sampel}

Jenis data penelitian yaitu data kuantitatif dari perusahaan nonkeuangan yang terdaftar di Bursa Efek Indonesia dalam waktu 2012 hingga 2016. Data yang dibutuhkan seperti perusahaan keluarga didapatkan dari laporan tahunan perusahaan. Selain itu, untuk mendukung perhitungan variabel dependen yaitu manajemen laba serta variabel kontrol di dapatkan dari Capital IQ.

Sampel didapatkan dengan menggunakan metode purposive sampling yaitu sampel dipilih sesuai kriteria yang ditentukan. Kriteria tersebut antara lain:

1. Perusahaan keluarga yang terdaftar pada Bursa Efek Indonesia (BEI), kecuali perusahaan keuangan.

2. Perusahaan dengan laporan keuangan serta laporan tahunan yang lengkap. 
Tabel 1

Perolehan Sampel Penelitian

\begin{tabular}{lc}
\hline \multicolumn{1}{c}{ Kriteria Pemilihan Sampel } & $\begin{array}{c}\text { Jumlah } \\
\text { Perusahaan }\end{array}$ \\
\hline Perusahaan yang terdaftar dalam BEI & 534 \\
\hline $\begin{array}{l}\text { Perusahaan keuangan yang terdaftar dalam BEI tahun 2012-2016 } \\
\text { Perusahaan non keuangan di Indonesia yang tidak mempublikasikan } \\
\text { laporan keuangan secara lengkap selama tahun 2012 - 2016 }\end{array}$ & $(5)$ \\
\hline Perusahaan yang digunakan sebagai sampel & 436 \\
\hline
\end{tabular}

\section{Pengukuran dan Operasionalisasi Variabel Penelitian}

Perhitungan variabel dependen menggunakan discretionary accrual sebagai proksi dari manajemen laba dan diukur menggunakan Modified Jones Model. Langkah perhitungan discretionary accrual yaitu sebagai berikut:

1. Menghitung Total Akrual

$$
\mathrm{TA}_{i t}=\mathrm{N}_{i t}-\mathrm{CFO}_{i t}
$$

2. Melakukan regresi dari persamaan Modified Jones (1995) pada setiap industri dan tahun

$$
\begin{aligned}
& \frac{T_{i t}}{A_{i t-1}}=\beta_{1}\left(\frac{1}{A_{i t-1}}\right)+\beta_{2}\left(\frac{\Delta \operatorname{Rev}_{t}}{A_{i t-1}}-\right. \\
&\left.\frac{\Delta \operatorname{Rec}_{t}}{A_{\text {it }-1}}\right)+\beta_{3}\left(\frac{\operatorname{PPE}_{t}}{A_{i t-1}}\right)+\varepsilon
\end{aligned}
$$

3. Menghitung akrual diskresioner yang didapatkan dari eror pada persamaan regresi. Dimana,
$\mathrm{TA}_{i t} \quad$ :Total Akrual perusahaan i pada tahun $\mathrm{t}$

$\mathrm{N}_{i t} \quad$ :Laba bersih perusahaan i pada tahun $\mathrm{t}$

$\mathrm{CFO}_{i t}$ :Aliran kas dari aktivitas operasi perusahaan i pada tahun $\mathrm{t}$

$\mathrm{A}_{i t-1}$ :Total Asset perusahaan i pada tahun t-1

$\Delta \operatorname{Rev}_{t}$ : Selisih pendapatan perusahaan pada tahun $\mathrm{t}$

$\mathrm{PPE}_{t}$ :Nilai Property, Plant and Equipment perusahaan pada tahun $\mathrm{t}$

$\Delta \operatorname{Rec}_{t}$ :Selisih nilai piutang perusahaan pada tahun $\mathrm{t}$

Variabel independen kepemilikan/kontrol keluarga, kriteria yang digunakan untuk mengukur kepemilikan keluarga pada penelitian ini yaitu sebuah perusahan keluarga ditandai dengan adanya kepemilikan saham keluarga dalam perusahaan dan (atau) keluarga menempati posisi manajemen perusahaan (Anderson dan Reeb, 2003). Secara ringkas, operasionalisasi variabel dapat dilihat pada Tabel 2.

Tabel 2

Operasionalisasi Variabel

\begin{tabular}{|l|l|l|c|}
\hline \multicolumn{1}{|c|}{ Variabel } & \multicolumn{1}{|c|}{ Simbol } & \multicolumn{1}{c|}{ Keterangan } & Rumus \\
\hline $\begin{array}{l}\text { Variabel Dependen : } \\
\text { Manajemen Laba Mod Jones }\end{array}$ & DA & $\begin{array}{l}\text { Total akrual dikurangkan dengan } \\
\text { nondiskresioner akrual (absolut } \\
\text { diskresioner akrual) }\end{array}$ & DA $=T A-N D A$ \\
\hline $\begin{array}{l}\text { Variabel Independen : Family } \\
\text { Own }\end{array}$ & FAM & $\begin{array}{l}\text { Variabel dummy, } 1 \text { jika ada } \\
\text { kontrol keluarga pada perusahaan } \\
\text { 0 jika lainnya }\end{array}$ & Lev $=\frac{\text { Total Liabilities }}{\text { Total Assets }}$ \\
\hline Variabel Kontrol : Leverage & LEV & $\begin{array}{l}\text { Total liabilities and total assets } \\
\text { perusahaan i pada tahun } \mathrm{t}\end{array}$ & ROA $=\frac{\text { Net Income }}{\text { Total Assets }}$ \\
\hline Variabel Kontrol : ROA & ROA & $\begin{array}{l}\text { Rasio net income terhadap aset } \\
\text { perusahaan i pada tahun t }\end{array}$ &
\end{tabular}




\begin{tabular}{|l|l|l|l|}
\hline Variabel Kontrol : Growth & GROWTH & $\begin{array}{l}\text { Pertumbuhan penjualan } \\
\text { perusahaan i pada tahun t }\end{array}$ & $\begin{array}{l}\text { Growth } \\
=\frac{\text { Sales }_{t}-\text { Sales }_{t-1}}{\text { Sales }_{t-1}}\end{array}$ \\
\hline Variabel Kontrol : Firm Age & AGE & $\begin{array}{l}\text { Tahun didirikannya perusahaan i } \\
\text { pada tahun t }\end{array}$ & $\begin{array}{l}\text { Age } \\
=\text { Tahun penelitian } \\
- \text { tahun IPO }\end{array}$ \\
\hline Variabel Kontrol : Audit & AUD & $\begin{array}{l}\text { Variabel dummy, 1 apabila diaudit } \\
\text { oleh "Big Four", 0 jika lainnya }\end{array}$ & \\
\hline
\end{tabular}

\section{Model Penelitian}

Model penelitian yang digunakan dalam penelitian ini yaitu

$\mathrm{DA}_{\mathrm{it}}=\alpha_{\mathrm{it}}+\beta_{1} \mathrm{FAM}_{\mathrm{it}}+\beta_{2} \mathrm{LEV}_{\mathrm{it}}+\beta_{3} \mathrm{ROA}_{\mathrm{it}}+\beta_{4}$

$\mathrm{GROWTH}_{\mathrm{it}}+\beta_{5} \mathrm{AGE}_{\mathrm{it}}+\beta_{6} \mathrm{AUD}_{\mathrm{it}}+\varepsilon_{\mathrm{it}}$

Keterangan :

DA : Manajemen Laba

FAM : Kontrol Keluarga;

LEV : Leverage;

ROA : Return on Asset;

GROWTH : Pertumbuhan Penjualan;

AGE : Umur Perusahaan;

AUD : Auditor eksternal perusahaan;

$\varepsilon \quad$ : Error;

i $\quad$ : Perusahaan i $\mathrm{t} \quad$ : Tahun $\mathrm{t}$

\section{Analisis Data}

Data sampel sebanyak 436 perusahaan non-finansial yang terdaftar pada BEI pada periode 2012-2016 dianalisis menggunakan metode regresi generalized least squares (GLS). Uji asumsi klasik dilakukan untuk memenuhi asumsi yang disyaratkan penggunaan model regresi.

\section{Hasil dan Diskusi}

\section{Statistik Deskriptif}

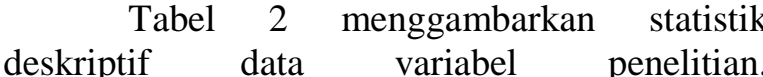

Tabel 2. Statistik Deskriptif

\begin{tabular}{|c|c|c|c|c|c|}
\hline Variabel & Perusahaan & & Observasi & \multicolumn{2}{|c|}{ Persentase } \\
\hline Family Own & 313 & & 1433 & \multicolumn{2}{|c|}{$71,65 \%$} \\
\hline Non Family Own & 123 & & 567 & \multicolumn{2}{|c|}{$28,35 \%$} \\
\hline Auditor (Big4) & 167 & & 737 & \multicolumn{2}{|c|}{$36,85 \%$} \\
\hline Auditor (NonBig4) & 269 & & 1263 & \multicolumn{2}{|c|}{$63,15 \%$} \\
\hline Variabel & Obs. & Mean & Std. dev & Min & $\operatorname{Max}$ \\
\hline Manajemen Laba & 2000 & 0,6735 & 1,9871 & 0 & 27,8957 \\
\hline Leverage & 2000 & 0,5728 & 0,8228 & 0.0004 & 16,8344 \\
\hline ROA & 2000 & 0,0168 & 0,3580 & $-10,9653$ & 2,1921 \\
\hline Growth & 2000 & 0,2353 & 2,718 & -1 & 103,0049 \\
\hline Firm Age & 2000 & 32.3675 & 17,187 & 2 & 132 \\
\hline
\end{tabular}

Tabel 2 menunjukkan bahwa sebagian besar sampel adalah perusahaan dengan kepemilikan keluarga (71.65\%). Sampel menunjukkan bahwa sebagian besar perusahaan diaudit oleh KAP
NonBig $4(63.15 \%)$. Secara rata-rata, sampel melakukan manajemen laba sebesar 0.67 berdasarkan perhitungan akrual diskresioner absolut. Variable leverage memiliki rata-rata 
$57 \%$ dan varabel ROA memiliki rata-rata $1.6 \%$. Secara rata-rata sampel memiliki tingkat pertumbuhan (growth) sebesar 23,5\% dengan umur perusahaan rata-rata telah bergerak di industrinya selama 32 tahun.

Tabel 3. Pengujian Hipotesis

\begin{tabular}{cccc}
\hline Modjones & Koefisien & $\mathbf{z}$ & P>IzI \\
\hline Familyown & 0,0675 & 1,39 & $0,0815^{*}$ \\
Leverage & $-0,2742$ & $-3,00$ & $0,0015^{* * *}$ \\
ROA & $-1,0895$ & $-3,48$ & $0,0000^{* * *}$ \\
Growth & 0,1446 & 1,95 & $0,0255^{* *}$ \\
Firm age & $-0,0022$ & $-1,75$ & $0,0405^{* *}$ \\
Audit & $-0,0261$ & $-0,64$ & 0,262 \\
\hline Kode Industri & Yes \\
\hline Tahun & Yes \\
\hline Prob > chi2 & 0 & \\
\hline R-squared overall & $* * *(1$ persen $), * *(5$ persen $), *(10$ persen $)$ \\
Tingkat signifikan &
\end{tabular}

\section{Uji Hipotesis}

Setelah melalui seluruh uji asumsi klasik dan penetapan model menggunakan random effect model, berikut adalah hasil pengujian hipotesis. Hasil dari tabel 3 menunjukkan bahwa variabel kontrol keluarga berpengaruh positif signifikan terhadap manajemen laba ( $p$-value: $0.08<\alpha, 0.1)$. Hal ini menunjukkan bahwa pada perusahaan keluarga lebih cenderung untuk melakukan tindakan manajemen laba yang lebih tinggi dibandingkan perusahaan nonkeluarga. Hasil penelitian ini mendukung penelitian Setia-Atmaja et al., (2011) yang menyatakan bahwa perusahaan keluarga memiliki akrual diskresioner yang lebih tinggi.

Menurut penelitian dari Siregar dan Utama (2008), perusahaan keluarga di Indonesia melakukan manajemen laba efisien. Hal ini dikarenakan perusahaan keluarga mementingkan keberlangsungannya dalam jangka panjang. Jakarta Consulting Group (2016) mengungkapkan bahwa perusahaan keluarga lebih berorientasi jangka panjang dengan cara lebih memilih untuk memproduksi dan memberikan layanan berkualitas tinggi, selalu inovatif, mengelola sumber daya manusia dengan baik, serta yang paling utama adalah tidak mengejar keuntungan sesaat. Bagi perusahaan keluarga, keuntungan dalam jangka pendek tidak bermanfaat apabila perusahaan mereka tidak bertahan lama karena tujuan utama dari perusahaan keluarga adalah bertahan dalam jangka panjang. Orientasi jangka panjang juga merupakan salah satu kekuatan sebuah perusahaan keluarga. Hal ini dikarenakan perusahaan keluarga tidak hanya memikirkan kepentingan saat ini, namun juga kepentingan anak-anaknya dalam jangka panjang demi menjaga dinasti keluarga. Dengan berorientasi jangka panjang maka reputasi bisnis dan keluarga dapat terjaga.

Selain itu, dengan hasil yang menunjukkan bahwa mayoritas perusahaan keluarga di Indonesia melakukan manajemen laba, maka sejalan dengan teori socio-emotional wealth yang dikemukakan oleh Kalm dan Gomez-Mejia (2016) bahwa keluarga akan bersedia membuat keputusan yang tidak dapat dijelaskan secara finansial dan tidak profesional menjadi logis untuk memenuhi keinginan keluarga dalam mencapai socio-emotional wealth. Oleh karena itu, teori dari socioemotional wealth ini mendukung adanya perilaku perusahaan keluarga di Indonesia untuk melakukan manajemen laba. Karena adanya kebutuhan afektif dari suatu perusahaan dengan kepemilikan keluarga untuk keberlangsungan dari suatu dinasti keluarga (Gómez-Mejía et al., 2007).

Variabel kontrol yang mendukung adanya praktik manajemen laba yaitu leverage, 
ROA, growth, firm age, dan audit. Variabel audit tidak memiliki pengaruh signifikan terhadap manajemen laba. Keberadaan auditor Big 4 belum mampu memberikan batasan bagi perusahaan di Indonesia dalam melakukan praktik manajemen laba. Namun, di sisi lain, variabel leverage, firm age, growth dan ROA memiliki pengaruh terhadap manajemen laba. Variabel ROA bersifat negatif signifikan yang berarti bahwa apabila tingkat profitabilitas perusahaan semakin tinggi, maka perusahaan cenderung memiliki manajemen laba yang lebih rendah. Hal ini dikarenakan profitabilitas mencerminkan efisiensi aset suatu perusahaan dalam menghasilkan laba. Dengan tingkat profitabilitas yang baik maka perusahaan cenderung memiliki manajemen laba yang lebih rendah.

Pada variabel growth bersifat positif signifikan yang berarti bahwa semakin tinggi pertumbuhan penjualan perusahaan, maka perusahaan memiliki manajemen laba yang lebih tinggi. Hal ini dikarenakan pertumbuhan penjualan perusahaan yang baik mencerminkan performa perusahaan yang dapat menarik investor. Dengan demikian, perusahaan dengan pertumbuhan penjualan yang baik cenderung memiliki manajemen laba yang lebih tinggi karena ingin menghindari penurunan pendapatan di masa yang akan datang.

Untuk variabel leverage dan firm age bersifat negatif signifikan yang menunjukkan bahwa semakin tinggi leverage dan semakin lama umur perusahaan, maka cenderung memiliki manajemen laba lebih rendah. Perusahaan dengan leverage yang tinggi cenderung melakukan manajemen laba lebih rendah karena perusahaan lebih banyak dikontrol oleh pihak ketiga. Semakin lama perusahaan berdiri juga menunjukkan tingkat manajemen laba yang rendah. Pada perusahaan yang lebih lama berdiri, kecenderungan untuk melakukan manajemen laba lebih kecil, sedangkan perusahaan yang baru berdiri cenderung memiliki manajemen laba yang lebih tinggi. Hal ini dikarenakan perusahaan yang baru berdiri belum mendapatkan kepercayaan dari investor, sehingga perusahaan cenderung melakukan manajemen laba untuk menarik investor.

Hasil pengujian variabel audit bersifat tidak signifikan terhadap manajemen laba. Hal ini menunjukkan bahwa variabel tersebut tidak mempengaruhi adanya manajemen laba. Hasil penelitian tersebut tidak sejalan dengan penelitian Almeida-Santos et al., (2013) yang menemukan bahwa variabel audit berpengaruh terhadap manajemen laba dengan tingkat signifikansi 1 persen.

Audit tidak memiliki pengaruh terhadap manajemen laba yang dapat diartikan bahwa pada perusahaan yang diaudit oleh KAP Big 4 maupun non KAP Big 4, tidak mengurangi adanya manajemen laba di perusahaan. Auditor memiliki peran dalam meningkatkan kredibilitas laporan keuangan. Hal ini dilakukan dengan melakukan beberapa prosedur dalam menemukan keabnormalan dan meningkatkan integritas pelaporan keuangan. Dalam penelitian ini, berarti auditor dan prosedurnya belum mampu membatasi perusahaan untuk mengurangi adanya praktik manajemen laba.

\section{Simpulan dan Saran}

Hasil penelitian ini memiliki tujuan yaitu untuk menganalisis apakah kontrol keluarga pada perusahaan di Indonesia mempengaruhi tindakan manajemen laba. Penelitian ini melalui regresi generalized least square (GLS) dari variabel dependen yaitu manajemen laba dengan proksi Modified Jones Model serta variabel independen yaitu kontrol keluarga pada perusahaan. Penelitian dilakukan pada 2,000 observasi dengan adanya kontrol dari variabel Leverage, ROA, Growth, Firm Age, audit. Hasil penelitian membuktikan hipotesis yang ada yaitu adanya pengaruh positif signifikan kontrol keluarga terhadap manajemen laba pada perusahaan nonfinansial yang terdafar di BEI periode 20122016.

Bagi dunia akademik, penelitian ini dapat memberikan pengetahuan bahwa semakin tinggi kontrol keluarga, maka semakin tinggi juga manajemen laba yang dilakukan. Penelitian ini juga dapat membantu menambah literatur bagi penelitian yang selanjutnya. Bagi investor dan pengguna laporan keuangan lainnya, penelitian ini dapat menjadi bahan pertimbangan yang dapat digunakan untuk pengambilan keputusan investasi dan dapat melihat lebih jelas akan tindakan serta karakteristik perusahaan keluarga di Indonesia.

Keterbatasan dalam penelitian ini yaitu pengklasifikasian perusahaan keluarga dan nonkeluarga bersifat subjektif karena terdapat beberapa informasi yang tidak dapat diperoleh pada proses pengklasifikasian perusahaan keluarga dan nonkeluarga. Hal yang sering ditemukan adalah pemegang saham private company dan perusahaan asing sehingga tidak dapat ditelusuri lebih lanjut untuk pengklasifikan perusahaan keluarga atau nonkeluarga. Penelitian ini juga tidak dapat menentukan apakah 
manajemen laba yang dilakukan oportunistik atau efisien secara lebih lanjut. Hal ini dikarenakan penelitian ini hanya menghitung akrual diskresioner dan tidak menghitung lebih lanjut dari segi future profitability.

Penelitian selanjutnya diharapkan dapat melengkapi segala keterbatasan penelitian ini dengan pengklasifikasian perusahaan keluarga menggunakan data ultimate ownership. Selain itu, melihat lebih lanjut mengenai tipe manajemen laba yang dilakukan di Indonesia dengan menambahkan variabel future profitability.

\section{Daftar Pustaka}

Almeida-Santos, P. S., Dani, A. C., Machado, D. G., \& Krespi, N. T. (2013). Influence of family control in the practice of earning management. Emerald Group, 11.

Anderson, R. C., \& Reeb, D. M. (2003). Founding-family ownership and firm performance: evidence from the S\&P 500. The Journal of Finance, 58(3), 1301-1328.

Anderson, R. C., \& Reeb, D. M. (2004). Board composition: Balancing family influence in S\&P 500 firms. Administrative Science Quarterly, 49(2), 209-237.

Bestivano, W. (2013). Pengaruh Ukuran Perusahaan, Umur Perusahaan, Profitabilitas, Leverage, Terhadap Perataan Laba pada Perusahaan yang terdaftar di BEI. Jurnal Akuntansi, 1(1), Ejournal.unp.ac.id.

Chen, S., Chen, X., \& Cheng, Q. (2008). Do family firms provide more or less voluntary disclosure? Journal of Accounting Research, 46, 1-54.

Chi, C. W., Hung, K., Cheng, H. W., \& Tien Lieu, P. (2015). Family firms and earnings management in Taiwan: Influence of corporate governance. Corporate Financing and Banks in Greater China, 36(Supplement C), 8898.

Chris Razook. (2016, November 15). Family businesses need good governance, too. The Jakarta Post.

Claessens, S., Djankov, S., \& Lang, L. H. . (2000). The separation of ownership and control in East Asian Corporations. Special Issue on International Corporate Governance, 58(1), 81-112.
DeAngelo, L. E. (1986). Accounting numbers as market valuation substitutes: A study of management buyouts of public stockholders. Accounting Review, 400420.

Dechow, P. M., Sloan, R. G., \& Sweeney, A. P. (1995). Detecting earnings management. Accounting Review, 193-225.

Diyanty, V., Utama, S., Rossieta, H., \& Veronica, S. (2013). Pengaruh Kepemilikan Pengendali Akhir, Kepemilikan Keluarga serta Praktek Corporate Governance Terhadap Transaksi Pihak Berelasi dan Kualitas Laba. Universitas Indonesia, (Corporate Governance, CSR dan Fraud $\&$ Forensic Accounting (CG)).

Family Firm Institute. (2008). Global Data Points. Retrieved from http://www.ffi.org/?page=GlobalDataPoi nts

Fan, J. P., \& Wong, T. J. (2002). Corporate ownership structure and the informativeness of accounting earnings in East Asia. Journal of Accounting and Economics, 33(3), 401-425.

Gómez-Mejía, L. R., Haynes, K. T., NúñezNickel, M., Jacobson, K. J., \& MoyanoFuentes, J. (2007). Socioemotional wealth and business risks in familycontrolled firms: Evidence from Spanish olive oil mills. Administrative Science Quarterly, 52(1), 106-137.

Healy, P. M. (1985). The effect of bonus schemes on accounting decisions. Journal of Accounting and Economics, 7(1), 85107.

Healy, P. M., \& Wahlen, J. M. (1999). A Review of the Earning Management Literature and Its Implication for Standard Settings.

Jaggi, B., Leung, S., \& Gul, F. (2009). Family control, board independence and earnings management: Evidence based on Hong Kong firms. Journal of Accounting and Public Policy, 28(4), 281-300.

Jakarta Consulting Group. (2014). Retrieved from http://www.jakartaconsulting.com/public ations/articles/family-business/menguakperusahaan-keluarga-di-indonesia

Jensen, M. C., \& Meckling, W. H. (1976). Theory of the firm: Managerial behavior, 
agency costs and ownership structure. Journal of Financial Economics, 3(4), 305-360.

Jiraporn, P., \& Dedalt, P. J. (2009). Does founding family control affect earnings management? Www.Tanfordonline.Com.

Kalm, M., \& Gomez-Mejia, L. R. (2016). Socioemotional wealth preservation in family firms. Revista de Administração (São Paulo), 51(4), 409-411.

Kothari, S., Leone, A., \& Wasley, C. (2005). Performance matched discretionary accrual measures. Journal of Accounting and Eco- nomics, 163-197.

La Porta, R., Lopez-De-Silanes, F., \& Shleifer, A. (1999). Corporate Ownership Around the World. The Journal of Finance, 54(2), 471-517.

Nayiroh, S. (2012). Analisis Faktor-Faktor yang Mempengaruhi Praktik Manajemen Laba. E-Journal Universitas Dian Nuswantoro.

Prencipe, A., Bar-Yosef, S., \& Dekker, H. C. (2014). Accounting Research in Family Firms: Theoretical and Empirical Challenges. European Accounting Review, 23(3), 361-385.

PriceWaterhouseCooper. (2014, November). Survey Bisnis Keluarga Indonesia. Retrieved from https://www.pwc.com/id/en/publications/ assets/indonesia-report-family-businesssurvey-2014.pdf

Rezeki, S., Azlina, N., \& Kurnia, P. (2016). Pengaruh Kepemilikan Keluarga, Praktek Good Corporate Governance, Profitabilitas Terhadap Manajemen Laba pada Perusahaan Listing di Bursa Efek Indonesia 2008-2012. Jurnal Online Mahasiswa (JOM) Bidang Ilmu Ekonomi, 2(1), 1-15.

Rusmin. (2010). Auditor Quality and Earnings Management: Singaporean Evidence. Managerial Auditing Journal, 25(7), 618-638.

Salvato, C., \& Moores, K. (2010). Research on accounting in family firms: Past accomplishments and future challenges. Family Business Review.

Setia-Atmaja, L., Haman, J., Tanewski, G. (2011). The role of board independence in mitigating agency problem II in
Australian family firms. The British Accounting Review.

Schulze, W. S., Lubatkin, M. H., Dino, R. N., \& Buchholtz, A. K. (2001). Agency Relationships in Family Firms: Theory and Evidence. Organization Science, 12(2), 99-116.

Scott, W. R. (2015). Financial Accounting Theory (seventh edition). Pearson Canada Inc.

Siregar, S. V., \& Utama, S. (2008). Type of earnings management and the effect of ownership structure, firm size, and corporate-governance practices: Evidence from Indonesia. The International Journal of Accounting 43.

Suyono, E. (2017). Berbagai model pengukuran earning management: mana yang paling akurat. Sustainable Competitive Advantage (SCA), 7(1).

Villalonga, Belen and Amit, Raphael. (2006). How do family ownership, control and management affect firm value? Journal of Financial Economics, (2), 385-417.

Widyastuti, T. (2009). Pengaruh struktur kepemilikan dan kinerja keuangan terhadap manajemen laba: Studi pada perusahaan manufaktur di BEJ. MAKSI, 9. 